\title{
Borsa İstanbul Sektör Endekslerinde Fiyat ile İşlem Hacmi İlişkisi
}

\author{
Sinem EYÜBOĞLU* Kemal EYÜBOĞLU **
}

\begin{abstract}
$\ddot{O} Z$
Fiyat-hacim ilişkisi, yatırımcıların yatırım kararı alırken belirli öngörüler yapabilmesine olanak sağlayabilmektedir. Bu çalışmanin amacı, 01.01.2012-02.01.2018 dönemi için Borsa İstanbul Sinai, Hizmet, Mali ve Kurumsal Yönetim endekslerindeki fiyat ve işlem hacmi arasindaki ilişkiyi günlük veriler kullanarak araştırmaktır. Toda-Yamamoto nedensellik testi sonuçlarına göre, sanayi endeksinde fiyattan hacme doğru tek yönlü bir nedensellik söz konusudur. Bu sonuç, Sanayi endeksinde Gürültücüler Hipotezinin geçerli olduğunu göstermektedir. Diğer endekslerde fiyathacim arasında bir nedensellik ilişkisi bulunamamıştır. Seriler arasındaki dinamik ilişki, etki-tepki analizi ve varyans ayrlştırma yöntemleri kullanılarak incelenmiş ve nedensellik testini destekleyen sonuçlara ulaşılmış̧ır.
\end{abstract}

Anahtar Kelimeler: Hisse Fiyatı, Işslem Hacmi, VAR Analizi, Toda-Yamamoto Nedensellik

Testi

JEL Sinıflandırması: G10, C22

\section{The Relationship Between Trading Volume and Prices in Borsa Istanbul Sector Indices}

\begin{abstract}
The relationship between price and volume may help investors to make predictions while making investment decisions. The purpose of this study is to investigate the relationship between trading volume and price in Borsa Istanbul Industrial, Services, Financial and Corporate Governance indices using daily data for the period 01.01.2012-02.01.2018. In the study, TodaYamamoto causality test results show that there is a one-way causality, running from price to volume in Industrial index. This result indicates that the Noise-Traders Hypothesis is valid in the Industrial index. For other indices, no causality relation is found between price and volume. The dynamic relationships between the series are examined by using impulse-response and variance decomposition methods, and results that support the causality test have been reached.
\end{abstract}

Key Words: Stock Price, Trading Volume, VAR analyze, Toda-Yamamoto Causality Test

JEL Classification: G10, C22

\section{GíRIŞ}

Zayıf formda etkin bir piyasada (Fama, 1970) cari hisse fiyatının, geçmiş fiyat bilgilerini tam olarak yansıttığı varsayılır. Diğer bir ifadeyle, fiyat hareketlerinin geçmişteki hareketlerle ilişkili olmadığı, tamamen tesadüfi olarak oluştuğu savunulmaktadır. Bu açıdan geçmişteki piyasa verilerini kullanarak geleceğe yönelik bir tahmin yapmak yararsız olacaktır. Piyasa verileri ise işlem hacmi ve fiyat gibi bilgileri kapsamaktadır. Dolayısıyla böyle bir piyasada teknik analize gerek duyulmayacaktır. Ancak teknik analizciler, geçmiş hisse

* Dr.Öğr.Üyesi, Avrasya Üniversitesi İ̈BF, Maliye Bölümü, email:sinemyilmaz17@ @otmail.com

${ }^{* *}$ Doç.Dr. Karadeniz Teknik Üniversitesi İ̉BF, İşletme Bölümü email: keyuboglu @ msn.com

(Makale Gönderim Tarihi: 07.05.2018 / Yayına Kabul Tarihi: 28.11.2018)

Doi Number: 10.18657/yonveek.421488 
fiyatlarındaki bilgilerin mevcut hisse fiyatlarına tam olarak yansımadığını, fiyatın bir trend halinde seyrettiğini ve dolayısıyla geçmiş hisse fiyatlarının gözlemlenmesiyle gelecek hisse fiyatlarının tahmin edilebileceğini öngörmektedirler.

Hisse fiyatları ve işlem hacmi yatırımcıların davranışları, yatırım stratejileri ve piyasanın genel yapısı açısından menkul kıymet piyasaları için iki önemli değişkeni ifade etmektedir (Büberkökü, 2017, s. 457). Günümüzde hisse fiyat-hacim grafikleri yatırım kararı alırken teknik analizciler tarafından sıklıkla kullanılmaktadır. Fiyat ve hacim, her türlü ekonomik dengenin iki önemli unsurudur ve ortak piyasa dinamikleri ile belirlenir. Dolayısıyla, genel olarak bu iki değişkenin çok yakın ve doğrudan ilişkiye sahip olduğuna inanılmaktadır. İşlem hacimlerinin dikkate alınması, teknik analizciler için oldukça önemli bir araçtır. Bu kişiler gelecekteki fiyat hareketlerini geçmişteki işlem hacimlerini dikkate alarak tahmin etmeye çalışırlar. Genellikle yüksek işlem hacmi mevcut trendin devam edeceğini gösterirken, düşük işlem hacmi ise mevcut trendin değişeceğine işaret etmektedir.

Karpoff (1987) ise hisse fiyatı ile işlem hacmi arasındaki ilişkinin önemini dört madde ile ifade etmiştir (Badhani \& Suyal, 2005, s. 3).

- Fiyat-hacim ilişkisi incelenerek piyasanın yapısı hakkında bilgi edinilebilir. Çünkü fiyat-hacim ilişkisi piyasaya olan bilgi akış hızına, bilginin nasıl dağıtıldığına, fiyatın bu bilgiyi ne ölçüde kapsadığına, piyasanın büyüklüğüne ve açığa satışın varlığına bağlıdır.

- Fiyat-hacim ilişkisinin doğru bir şekilde anlaşılması, çeşitli olay çalışmalarının yürütülmesi ve çıkarımların yapılabilmesi için de yararlıdır.

- Fiyat-hacim ilişkisi incelenerek, fiyatların ne kadar spekülatif olabileceği konusunda fikir edinilebilir.

- Fiyat-hacim ilişkisi incelenerek vadeli işlemler piyasası için de çıkarımlar yapılabilir. Fiyat değişkenliği vadeli işlem sözleşmelerinde ticaret hacmini etkiler. Bu etkileşim, spekülasyonun vadeli fiyatlarda istikrarı sağlayıcı veya bozucu faktör olup olmadığını belirler.

Gallant vd. (1992)'de finansal analiz yaparken sadece hisse fiyatlarına odaklanmaktan ziyade, hisse fiyatını ile işlem hacmini birlikte ele almanın piyasa hakkında daha fazla bilgi edinilmesini sağlayacağını ifade etmiştir. Literatürde fiyat-işlem hacmi arasındaki ilişkiyi açıklayan çeşitli hipotezler bulunmaktadır. Bunlardan ilki, Copeland (1976) ile Jennings vd. (1981) tarafından geliştirilen Ardışık Bilgi Akışı (Sequential Arrival Information) hipotezidir. Bu hipoteze göre fiyat ve hacim arasında pozitif bir ilişki olduğu, aynı zamanda nedensellik ilişkisinin de çift yönlü olduğu savunulmaktadır. Bu hipoteze göre, hisse ile ilgili piyasaya yeni bir bilgi geldiğinde, bu bilgi aynı anda tüm piyasa katılımcılarına ulaşamamaktadır. $\mathrm{Bu}$ nedenle, gecikmeli işlem hacminin, mevcut hisse getirilerinin; gecikmeli hisse getirilerinin de, mevcut işlem hacminin öngörülebilmesinde kullanılabileceği ileri sürülmektedir (Copeland, 1976; Jennings vd. 1981). 
İkincisi Clark (1973) ile Epps \& Epps'in (1976) Bilgi Dağılımı Karışım (Mixture of Distributions) hipotezidir. Bu hipotez, Ardışık Bilgi Akışının aksine, fiyat ile hacim arasında çift yönlü nedensellik ilişkisinin yerine, işlem hacminden hisse getirisine doğru tek yönlü bir nedensellik ilişkisi olduğunu öne sürmektedir. $\mathrm{Bu}$ modele göre, işlem hacmi, piyasa katılımcıları arasındaki bilgi asimetrisinin önemli bir ölçütüdür. Piyasaya yeni bilgiler ulaştığında piyasa katılımcıları arasındaki bilgi asimetrisi daha da artmaktadır (Jiranyakul, 2016, s. 1).

Bu iki hipotez kadar literatürde ilgi gören bir diğer hipotez ise Delong vd. (1990) tarafından ortaya konan Gürültü̈cüler Hipotezi'dir (Noise-Traders Hypothesis). $\mathrm{Bu}$ model, gürültücülerin analizlerini ekonomik temellere dayandırmadıklarını ve dolayısıyla bu durumun kısa vadede geçici olarak yanlış fiyatlamaya neden olduğunu ileri sürmektedir. Fiyatın, uzun vadede ortalama değere doğru hareket etmesi ile birlikte, bu hipotez geri besleme yatırım stratejisi ile uyumlu olarak, fiyatlardan işlem hacmine doğru pozitif ve tek yönlü bir nedensellik ilişkisinin söz konusu olduğunu vurgulamaktadır. Bunun da gürültücülerin yatırım kararlarını, hisse senetlerinin geçmiş fiyat hareketleri üzerine dayandırmasından kaynaklandığını ifade etmektedir (Moosa \& Silvapulle, 2000, s. 13-14).

Literatürde hisse fiyatlarının işlem hacimlerini etkileyip etkileyemeyeceği ya da işlem hacimlerindeki değişimlerin hisse fiyatlarını etkileyip etkilemeyeceği pek çok kez araştırılmıştır. Bu çalışmalarda daha çok borsaları temsil eden temel endeks (örneğin BIST-100, S\&P500 gibi) veya bankacılık endeks değeri ve hacmi üzerine odaklanılmıştır. Bu çalışmada ise fiyat-hacim ilişkisinin durumu, aynı ülke piyasasındaki farklı endeksler (sınai, mali, hizmetler ve kurumsal yönetim) açısından karşılaştırmalı olarak ele alınmıştır.

Çalışmanın bundan sonraki bölümünde işlem hacmi ile hisse fiyatları arasındaki ilişkiyi inceleyen çalışmalar özetlenecektir. Üçüncü bölümde ise çalışmada kullanılan veri seti ile yöntemler açıklanacaktır. Çalışmanın son bölümünde ise yapılan analizler sonucu elde edilen bulgular sunulacaktır.

\section{LITERATÜR TARAMASI}

Fiyat-hacim ilişkisine dair literatür incelendiğinde, farklı farklı sonuçlara ulaşıldığ görülmektedir. Bazı çalışmalarda fiyat ile hacim arasında herhangi bir ilişkiye rastlanılmamıştır. Örneğin fiyat-hacim ilişkisini konu alan ilk çalışmalardan Granger \& Morgenstern, (1963) ABD’de 1915-1961 dönemi için endeks getirileri ile işlem hacimleri arasında ilişki olup olmadığını incelemiş ve ilişkinin varlı̆̆ına dair herhangi bir bulguya ulaşamamışlardır. Darrat vd. (2003) 1 Nisan 1998-30 Haziran 1998 dönemi için Dow Jones Sanayi endeksindeki otuz hisse için getiri oynaklığ 1 ile işlem hacmi arasındaki ilişkiyi analiz etmişlerdir. Çalışma sonucunda endekste yer alan hisse senetlerinin birçoğunda getiri ile işlem hacmi arasında bir ilişki olmadığı gözlemlenmiştir. Gündüz \& Hatemi-J (2005) her ülke için farklı dönemleri dikkate alarak Çekya, Macaristan, Polonya, Rusya ve Türkiye hisse senedi piyasalarında fiyat ile hacim arasındaki nedensellik ilişkisini test etmişlerdir. Buna göre Çekya'da fiyat ile hacim arasında nedensellik ilişkisi tespit edilememiştir. Türkiye'de ise Bayrakdaroğlu \& Nazlığlu (2009) on 
banka hissesini dikkate alarak yaptıkları çalışmada, fiyat ile hacim arasında beş banka için doğrusal bir nedensellik ilişkisinin olmadığını saptamışlardır.

Bazı çalışmalarda ise fiyat ile hacim arasında pozitif ilişki bulunmuştur. Copeland (1976) hisse fiyat değişimleri ile işlem hacmi arasındaki ilişkiyi incelemiş ve iki değişken arasında pozitif ilişki olduğunu belirlemiştir. Tauchen \& Pitts (1983), 1976-1979 dönemi için ABD'de hisse fiyatlarındaki değişim ile işlem hacmi arasındaki ilişkiyi incelemiş ve sonuç olarak iki değişken arasında pozitif bir ilişki olduğunu belirlemiştir. Lamoureux \& Lastrapes (1990) ABD'de CBOE'de işlem gören yirmi hisseyi ele alarak hacim-getiri oynaklığı arasında herhangi bir ilişki olup olmadığını test etmiş ve hacim-getiri oynaklığı arasında pozitif bir ilişkinin var olduğunu tespit etmişlerdir. Chen vd. (2001), 1973-2000 yılları arasını dikkate alarak ABD, Japonya, İngiltere, Fransa, Kanada, İtalya, İsviçre Hollanda ve Hong Kong hisse senedi piyasalarında, getiriler ile işlem hacimleri arasında ilişki olup olmadığını analiz etmişlerdir. Yapılan analizler sonucunda hisse getirileri ile işlem hacimleri arasında pozitif bir ilişki olduğu belirlenmiştir. Al-Deehani (2007) sekiz farklı ülkedeki dokuz hisse senedi piyasasını dikkate alarak (ABD DJIA, S\&P500, İngiltere FTSE 100, Fransa CAC40, İspanya MadGen, Japonya Nikkie 225, Hong Kong HS, Güney Kore Seoul ve Kanada S\&P/TSX) işlem hacmi ile endeks değeri arasındaki ilişkiyi incelemiştir. Sonuçtaa iki değişken arasındaki asimetrik ilişkinin varlığ 1 ve yüksek işlem hacminin, fiyatlardaki azalıştan ziyade fiyat artışlarıyla ilişkili olduğu bulunmuştur. Pathirawasam (2011) Kolombiya'da 2000-2008 dönemi için hisse getirileri ile işlem hacmi arasındaki ilişkiyi incelemiş ve getirilerin işlem hacmi ile pozitif yönde ilişkili olduğu tespit edilmiştir. Chuang vd. (2012) Hong Kong, Japonya, Güney Kore, Singapur, Tayvan, Çin, Endonezya, Malezya, Filipinler ve Tayland hisse senedi piyasalarını incelemiş ve Hong Kong, Güney Kore, Singapur, Çin, Endonezya ve Tayland'da hacim ile getiri oynaklığı arasında pozitif ilişki saptanmıştır. Jiranyakul (2016) 2004-2015 dönemi için günlük verileri kullanarak getiri, hacim ve oynaklık arasındaki ilişkiyi Tayland borsası açısından analiz etmiştir. Sonuç olarak işlem hacminin seriler arasındaki dinamik ilişkide baskın bir rolü olduğunu ortaya koymuştur.

Bazı çalışmalar ise fiyat ile hacim arasındaki nedensellik ilişkisi test etmiş ve hacmin fiyatın nedeni olduğunu belirlemişlerdir. Örneğin Epps \& Epps (1976), New York Borsası'nda işlem gören yirmi hisseyi dikkate alarak hisse fiyat değişimleri ve işlem hacmi arasında ilişkiyi araştırmışlardır. Çalışma sonucunda işlem hacminden hisse getirilerine doğru pozitif bir nedensellik ilişkisi olduğu saptanmıştır. Saatcioglu \& Starks (1998) 1986-1995 dönemi için Arjantin, Brezilya, Şili, Kolombiya, Meksika ve Venezüella hisse piyasasında aylık verileri dikkate alarak getiriler ile işlem hacmi arasındaki ilişkiyi araştırmışlardır. Çalışma sonucunda ise Arjantin ve Şili dışındaki dört ülke hisse piyasasında hacimden hisse senetlerine doğru bir nedensellik olduğu bulunmuştur. Türkiye'de ise Yılancı \& Bozoklu (2014) 1990-2012 dönemi için BIST-100 endeksinde hisse işlem hacmi ve fiyat ilişkisini test etmişlerdir. Çalışma sonucunda, işlem hacminden hisse fiyatlarına doğru tek yönlü bir nedensellik ilişkisinin olduğu ve 
bu ilişkinin zamana bağlı olarak değiştiği tespit edilmiştir. Zor vd. (2016) BIST100 ile BIST İkinci Ulusal endekslerinde 1986-2014 dönemi için fiyat ile işlem hacmi ilişkisini araştırmışlardır. İkinci Ulusal Pazar'da ise işlem hacminden fiyat değişimine doğru tek yönlü nedensellik ilişkisinin olduğu belirlenmiştir.

Bazı çalışmalarda ise fiyatın hacmin nedeni olduğuna dair bulgulara ulaşılmıştır. Örneğin Chen vd. (2001), 1973-2000 yılları arasını dikkate alarak ABD, Japonya, İngiltere, Fransa, Kanada, İtalya, İsviçre Hollanda ve Hong Kong hisse senedi piyasalarında, getiriler ile işlem hacimleri arasında ilişki olup olmadığını test etmişlerdir. Yapılan analizler sonucunda getirinin hacmin nedeni olduğu saptanmıştır. Badhani \& Suyal (2005) Hindistan S\&P CNX Nifty borsasında 1995-2005 dönemini dikkate alarak fiyat ile hacim arasindaki nedensellik ilişkisini incelemişlerdir. Çalışma sonucunda fiyattan hacme doğru tek yönlü bir nedensellik ilişkisi olduğu belirlenmiştir. ündüz \& Hatemi-J (2005) her ülke için farklı dönemleri dikkate alarak Çekya, Macaristan, Polonya, Rusya ve Türkiye hisse senedi piyasalarında fiyat ile hacim arasındaki nedensellik ilişkisini araştırmışlardır. Rusya ve Türkiye'de fiyatın işlem hacminin nedeni olduğu saptanmıştır. Türkiye'de ise Gökçe (2002) 1988-2001 dönemi için BIST100 'de işlem hacmi ile fiyat değişimleri arasındaki ilişkiyi incelemiş ve fiyat değişimlerinin işlem hacmindeki değişikliklerin Granger nedeni olduğunu belirlemiştir. Sarıoğlu (2007) 1991-2006 yılları arasını kapsayan çalışmalarında BIST-100 Endeksinde fiyat hacim ilişkilerini test etmiştir. Yapılan analizler sonucunda fiyatın hacmin nedeni olduğu sonucuna ulaşmıştır. Umutlu (2008) 2002-2007 dönemini kapsayan çalışmasında, BIST-Ulusal Tüm Endeksi için hisse fiyatları ve işlem hacmi değişimleri arasında dinamik ve nedensel bir ilişki olup olmadığını araştırmıştır. Çalışma sonucunda, fiyat değişimlerinden işlem hacmi değişimlerine doğru tek yönlü bir nedensellik bulunmuştur. Ayrıca VAR analizleri, fiyat ve işlem hacmi değişmelerinin gecikmeli dört günlük değerlerinin, işlem hacminin gelecekteki değişimlerini etkileyebileceğini ortaya koymuştur. Gaygusuz (2008) 1987-2007 dönemi için BIST-100 endeksinde hisse getirileri ve işlem hacimleri arasındaki nedensellik ilişkisini araştırmış ve nedenselliğin yönünün hisse getirilerinden işlem hacmine doğru olduğunu tespit etmiştir. Elmas \& Temurlenk (2009) farklı sektörlerde faaliyet gösteren dokuz şirketi ele alarak getiri-hacim ilişkisini incelemiş ve şirketlerden yedisinde hisse getirilerinden işlem hacmine doğru tek yönlü bir nedensellik ilişkisi olduğu sonucuna ulaşmışlardır. Elmas \& Yıldırım (2010) BIST bankacılık hisseleri için fiyat-hacim arasındaki nedensellik ilişkisini araştırmışlardır. Yapılan analizler sonucunda bankacılık sektöründe hisse getirisinden (fiyatından-endeksinden) işlem hacmine doğru bir nedensellik olduğu; işlem hacminden hisse getirisine (fiyatına) doğru bir nedensellik ilişkisinin olmadığı tespit edilmiştir. Çukur vd. (2012) 1990-2011 dönemi için BIST-100 endeksinde fiyat ile işlem hacmi arasındaki dinamik ilişsileri test ettikleri çalışmaları sonucunda, fiyattan işlem hacmine doğru tek yönlü bir nedensellik ilişkisi olduğunu ortaya koymuşlardır. Nalın \& Güler (2013) BIST-100 endeksinde 1987-2013 dönemi için işlem hacmi ile getiri arasında dinamik ilişkiyi araştırmışlardır. Buna göre çalışmadan elde edilen bulgular işlem 
hacmi ile getiri arasında uzun dönemli bir ilişki olduğunu ortaya koymuştur. Ayrıca işlem hacmi ile getiri arasında tek yönlü bir nedensellik ilişkisi elde edilmiştir. Zor vd. (2016) BIST-100 ile BIST İkinci Ulusal endekslerinde 19862014 dönemi için fiyat ile işlem hacmi ilişkisini araştırmışlardır. Analiz sonucunda Ulusal Pazar'da, fiyat değişiminden işlem hacmine doğru nedensellik tespit edilmiştir. Taş vd. (2016) 2000-2014 dönemi için BIST-100'de işlem hacmi ve getiri arasında eşanlı ve dinamik bir ilişki bulmuş, fiyat değişimlerinin işlem hacimlerini etkilediğini gözlemlemişlerdir. Nedensellik testi sonuçları ise fiyat ile hacim hareketleri arasındaki ilişkinin tek yönlü ve fiyattan hacme doğru olduğunu göstermiştir. Büberkökü (2017) 2002-2015 dönemi için BIST'te işlem gören on banka hisse için işlem hacmi ile hisse getirileri arasındaki ilişkiyi incelemiştir. Yapılan analiz sonucu hisse getirilerinin işlem hacmi üzerindeki etkisinin belirgin bir şekilde daha fazla olduğu belirlenmiştir. Nedensellik testi sonuçları bankaların sekizinde hisse fiyatlarından işlem hacmine doğru tek yönlü ve pozitif bir nedensellik ilişkisi olduğunu, ikisinde ise pozitif ve çift yönlü nedensellik ilişkisi olduğunu göstermiştir.

Son olarak bazı çalışmalarda fiyat ile hacim arasında çift yönlü nedensellik ilişkisi olduğu belirlenmiştir. Gündüz \& Hatemi-J (2005) her ülke için farklı dönemleri dikkate alarak Çekya, Macaristan, Polonya, Rusya ve Türkiye hisse senedi piyasalarında fiyat ile hacim arasındaki nedensellik ilişkisini incelemişlerdir. Macaristan ve Polonya'da iki değişken arasında çift yönlü nedensellik ilişkisi olduğu belirlenmiştir. Deo vd. (2008) 2004-2008 dönemi için yedi Asya-Pasifik ülkesi hisse senedi piyasasında fiyat ile hacim ilişkisini incelemiş ve iki değişken arasında istatistiksel açıdan anlamlı bir ilişki olduğunu belirlemiştir. İlaveten birçok piyasa için hacim ile getiri arasında çift yönlü nedensellik olduğu vurgulanmıştır. Darwish (2012) Filistin'de 2000-2010 yılları arasını kapsayan çalışmasında hisse getirileri ile hacim arasında çift yönlü ilişki olduğunu tespit etmiştir. Ong (2015) 1980-2012 dönemi için S\&P500 endeksini incelediği çalışmasında işlem hacmi ile hisse getirileri arasında çift yönlü bir nedensellik ilişkisi olduğunu gözlemlemiş̧ir. Türkiye'de Yörük vd. (2006) 1998 2003 dönemi için banka hisse senetlerinde fiyat-işlem hacmi ilişkisini araştırmış ve işlem hacmi ile hisse fiyatları arasında çift yönlü nedensellik olduğunu saptamıştır. Akar (2008) 1997-2005 dönemi için BIST-100 endeks değeri ile net yabancı işlem hacmi arasındaki nedensellik ilişkisinin varlığını test ettiği çalışmasında, elde edilen sonuçlar çift yönlü nedenselliğe işaret etmiştir. Boyacioğlu vd. (2010) BIST- 100 Endeksinde 1997-2009 dönemi için aylık verileri kullanarak fiyat ile hacim arasındaki ilişkiyi incelemişılerdir. Çalışmada volatilite ile işlem hacmi arasında çift yönlü nedensellik ilişkisinin olduğu belirlenmiştir.

\section{VERI SETİ VE YÖNTEM}

01.01.2012-02.01.2018 dönemi için Borsa İstanbul Sanayi, Mali, Hizmetler ve Kurumsal Yönetim fiyat endeksleri ile bu endekslere ilişkin işlem hacimleri arasındaki ilişkinin araştırıldığı çalışmada, günlük verilerden 
yararlanılmıştır. Veri setinin 2012 yılından başlamasının nedeni 2012 itibariyle dünya ve Türkiye ekonomisinin görece olarak daha istikrarlı hale gelmiş olduğunun düşünülmesidir. Analizlerde günlük verilerin kullanılmasının çeşitli avantajları vardır. Örneğin Copeland (1991) günlük verilerle çalışmanın ekonometrik açıdan daha fazla bilgi kullanımına imkan verdiğini, Eun ve Shim (1989) ise günlük verilerin potansiyel etkileşimi yakalamada haftalık ve aylık verilere kıyasla daha faydalı olabileceğini ifade etmişlerdir. Endeks fiyat ve işlem hacmi verileri Borsa İstanbul'dan elde edilmiş ve çalışmada serilerin doğal logaritmik halleri kullanılmıştır.

Çalışmada öncelikle serilerin durağan oldukları seviyelerin belirlenmesi amacıyla Genişletilmiş Dickey-Fuller (ADF) ve Phillips-Perron (PP) birim kök testleri kullanılmıştır. Seriler arasındaki dinamik ilişkiler ise VAR analizi ile araştırılmıştır. Sims (1980) tarafından oluşturulan VAR formunda içsel değişkenin gecikmeli değerlerinin denklemin sağında yer alması dolayısıyla otoregresif bir yapı oluşmakta ve iki ya da daha çok değişkenden oluşan bir vektör ele alınmaktadır (Umutlu, 2008, s. 237). Çalışmada fiyat ile işlem hacmi arasındaki ilişkinin ortaya konulması için oluşturulan VAR modeli aşağıdaki gibidir.

$\Delta$ EndeksFiyat $_{t}=\sum_{i=1}^{k} \alpha_{11, k}$ DEndeksFiyat $t_{t-k}+\sum_{i=1}^{k} \alpha_{12, k}$ EndeksHacim $_{t-k}+\varepsilon_{1 t}$

EndeksHacim $_{t}=\sum_{i=1}^{k} \alpha_{21, k}$ DEndeksFiyat $t_{t-k}+\sum_{i=1}^{k} \alpha_{22, k}$ EndeksHacim $_{t-k}+\varepsilon_{2 t}$

VAR modeli tüm değişkenleri içsel olarak kabul eder ve sistem bütünlüğü içerisinde inceler. Modelde $\mathrm{k}$ gecikme sayısını, $\varepsilon$ ise hata terimini ifade etmektedir. VAR modelinde değişkenlere ait optimal gecikme uzunlukları (k), Akaike ve Schwartz bilgi kriterlerine göre belirlenmektedir. VAR analizinde etkitepki ve varyans ayrıştırma analizlerinden elde edilen sonuçlar da gösterilmektedir. Etki-tepki analizinde, serilerden herhangi birine bir birimlik şok uygulandığında hem kendisinin, hem de diğer serilerin bu şoka vermiş olduğu tepkiler gözlemlenmektedir. Bu şekilde değişkenler arasındaki dinamik ilişkiler incelenebilmektedir. Varyans ayrıştırmada ise, belirli bir dönemde serilerin her birinin varyansında meydana gelen değişmenin yüzde kaçının kendisi ve diğer seriler tarafından açıklandığı rapor edilmektedir.

Nedensellik testleri, hissenin geçmiş fiyat hareketlerinin, işlem hacminin mevcut veya gelecekteki hareketlerinin kısa vadede öngörülebilmesine yardımcı olup olamayacağına veya tam tersi şekilde, işlem hacmindeki geçmiş hareketlerin, fiyatın mevcut veya gelecekteki hareketlerinin kısa vadede öngörülebilmesine yardımcı olup olamayacağına ilişkin yararlı bilgiler sağlayabilir (Hiemstra \& Jones, 1994, s. 1639). Endeks değerleri ile endeks işlem hacimleri aynı seviyede durağan olmadığından seriler arasındaki nedensellik ilişkisi Toda-Yamamoto nedensellik testi ile araştırılmıştır. Bu açıdan çalışmada seriler arasındaki nedensellik ilişkisi Toda-Yamamoto nedensellik testi ile araştırılmıştır. VAR sistemine dayalı testte serilerin eşbütünleşik olup olmaması 
önemli değildir. Buna göre $\mathrm{Y}$ ve X serilerine ait verilerin seviye değerlerinin yer aldığı iki değişkenli model aşağıdaki gibidir.

$$
\begin{aligned}
& Y_{t}=\lambda_{1}+\sum_{i=1}^{k} a_{1 i} Y_{t-i}+\sum_{j=k+1}^{d_{\max }} a_{2 j} Y_{t-j}+\sum_{i=1}^{k} \beta_{1 i} X_{t-i}+\sum_{j=k+1}^{d_{\max }} \beta_{2 j} X_{t-j}+e_{1 t} \\
& X_{t}=\lambda_{2}+\sum_{i=1}^{k} a_{2 i} Y_{t-i}+\sum_{j=k+1}^{d_{\max }} a_{2 j} Y_{t-j}+\sum_{i=1}^{k} \beta_{2 i} X_{t-i}+\sum_{j=k+1}^{d_{\max }} \beta_{2 j} X_{t-j}+e_{2 t}
\end{aligned}
$$

(3) numaralı denkleme göre $\mathrm{X}$ değişkeninden $\mathrm{Y}$ değişkenine doğru bir nedensellik ilişkisinin olduğunu söyleyebilmek için $\beta_{11}$ 'lerin bir bütün olarak sıfırdan farklı olması gerekir. Benzer şekilde (4) numaralı denkleme göre ise Y değişkeninden $\mathrm{X}$ değişkenine doğru bir nedensellik ilişkisi $\alpha_{2 \mathrm{i}}{ }^{\prime}$ lerin birlikte sıfırdan farklı olması ile mümkündür (Ulusoy vd., 2016: 19).

\section{BULGULAR}

Tablo 1'de çalışmada yer alan serilere ilişkin tanımlayıcı istatistikler gösterilmiştir. Buna göre, en yüksek ve en düşük oynakllğa sahip fiyat endekslerinin ve işlem hacimlerinin surasıyla XUHIZ ve XUMAL endekslerine ait olduğu belirlenmiştir.

\begin{tabular}{|c|c|c|c|c|c|c|}
\hline Değișkenler & & 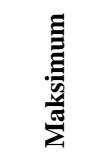 & 声 & 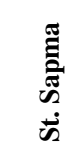 & 兰 & 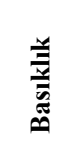 \\
\hline LXUSIN & 19.190 & 20.986 & 17.449 & 0.420 & 0.750 & 4.206 \\
\hline LXUMAL & 19.843 & 20.914 & 18.227 & 0.299 & -0.499 & 5.339 \\
\hline LXUHIZ & 18.600 & 20.118 & 16.777 & 0.520 & 0.096 & 2.615 \\
\hline LXKURY & 19.154 & 20.495 & 17.070 & 0.441 & -0.223 & 3.229 \\
\hline LXUSINV & 14.741 & 20.986 & 10.542 & 3.558 & 0.608 & 1.413 \\
\hline LXUMALV & 15.390 & 20.914 & 11.360 & 3.386 & 0.599 & 1.391 \\
\hline LXUHIZV & 14.150 & 20.118 & 9.869 & 3.696 & 0.591 & 1.392 \\
\hline LXKURYV & 14.704 & 20.495 & 10.162 & 3.566 & 0.588 & 1.393 \\
\hline
\end{tabular}

Tablo 1. Tanımlayıcı İstatistikler

Çalışmada öncelikle ADF ve PP birim kök testleri yardımıyla serilerin durağan oldukları seviyeler belirlenmiş̧tir. Tablo 2 incelendiğinde XUSIN, XUMAL, XUHIZ ve XKURY fiyat endekslerinin birinci farkında, XUSIN, XUMAL, XUHIZ ve XKURY işlem hacimlerinin ise seviyesinde durağan olduğu tespit edilmiştir.

Tablo 2. Serilere İlişskin Birim Kök Sonuçları

\begin{tabular}{|c|c|c|c|c|c|c|c|c|}
\hline & \multicolumn{4}{|c|}{ I (0) } & \multicolumn{3}{c|}{ I (1) } \\
\hline \multirow{2}{*}{ Seriler } & \multicolumn{2}{|c|}{ ADF } & \multicolumn{2}{c|}{ PP } & \multicolumn{2}{c|}{ ADF } & \multicolumn{2}{c|}{ PP } \\
\cline { 2 - 8 } & Sabitli & $\begin{array}{c}\text { Sabitli } \\
\text { ve } \\
\text { Trendli }\end{array}$ & Sabitli & $\begin{array}{c}\text { Sabitli } \\
\text { ve } \\
\text { Trendli }\end{array}$ & Sabitli & $\begin{array}{c}\text { Sabitli } \\
\text { ve } \\
\text { Trendli }\end{array}$ & Sabitli & $\begin{array}{c}\text { Sabitli } \\
\text { ve } \\
\text { Trendli }\end{array}$ \\
\hline LXUSIN & -0.321 & -2.011 & -0.293 & -2.022 & $-39.91^{\mathrm{a}}$ & $-39.91^{\mathrm{a}}$ & $-39.90^{\mathrm{a}}$ & $-39.90^{\mathrm{a}}$ \\
\hline
\end{tabular}




\begin{tabular}{|c|c|c|c|c|c|c|c|c|}
\hline LXUMAL & -2.561 & -3.087 & -2.552 & -3.095 & $-40.62^{\mathrm{a}}$ & $-40.60^{\mathrm{a}}$ & $-40.58^{\mathrm{a}}$ & $-40.57^{\mathrm{a}}$ \\
\hline LXUHIZ & -1.483 & -2.213 & -1.481 & -2.213 & $-38.99^{\mathrm{a}}$ & $-38.98^{\mathrm{a}}$ & $-38.99^{\mathrm{a}}$ & $-38.98^{\mathrm{a}}$ \\
\hline LXKURY & -1.589 & -2.295 & -1.577 & -2.314 & $-40.00^{\mathrm{a}}$ & $-39.99^{\mathrm{a}}$ & $-39.99^{\mathrm{a}}$ & $-39.97^{\mathrm{a}}$ \\
\hline LXUSINV & $-3.075^{\mathrm{b}}$ & $-4.321^{\mathrm{a}}$ & $-9.279^{\mathrm{a}}$ & $-14.64^{\mathrm{a}}$ & & & & \\
\hline LXUMALV & $-5.473^{\mathrm{a}}$ & $-6.300^{\mathrm{a}}$ & $-21.04^{\mathrm{a}}$ & $-21.37^{\mathrm{a}}$ & & & & \\
\hline LXUHIZV & $-3.132^{\mathrm{b}}$ & $-6.226^{\mathrm{a}}$ & $-9.480^{\mathrm{a}}$ & $-20.79^{\mathrm{a}}$ & & & & \\
\hline LXKURYV & -4.295 & $-5.712^{\mathrm{a}}$ & $-16.18^{\mathrm{a}}$ & $-20.99^{\mathrm{a}}$ & & & & \\
\hline
\end{tabular}

${ }^{\mathrm{a} \text { ve }}$ sirasıyla $\% 1$ ve $\% 5$ anlamlılık düzeylerini göstermektedir.

Tablo 3'te Toda-Yamamoto nedensellik testine ilişkin elde edilen bulgular yer almaktadır. Buna göre, sadece XUSIN için endeks değerinin işlem hacminin nedeni olduğu belirlenmiştir. Bu sonuç, Gürültücüler Hipotezi'nin (Noise Trader Hypothesis) XUSIN endeksinde geçerli olduğunu ortaya koymaktadır. Söz konusu endeksteki yatırımcıların fiyat hareketlerini takip ettikleri, fiyat hareketlerine bağlı olarak alım-satım kararlarını verdikleri söylenebilir.

Tablo 3. Toda-Yamamoto Nedensellik Testi Sonuçları

\begin{tabular}{|c|c|c|}
\hline Nedenselliğin Yönü & Gecikme uzunluğu $\left(\mathrm{d}_{\max }=1\right)$ & $\mathbf{X}^{2}$-ist. \\
\hline $\begin{array}{ll}\text { XKURY } & \text { XKURYV } \\
\text { XKURYV } & \rightarrow \text { XKURY }\end{array}$ & 6 & $\begin{array}{l}7.332 \\
5.111\end{array}$ \\
\hline $\begin{array}{ll}\text { XUSIN } & \text { XUSINV }^{\text {XUSINV }} \longrightarrow \text { XUSIN }\end{array}$ & 7 & $\begin{array}{l}30.39^{\mathrm{a}} \\
8.127\end{array}$ \\
\hline 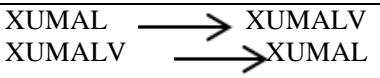 & 6 & $\begin{array}{l}6.524 \\
3.436\end{array}$ \\
\hline $\begin{array}{ll}\text { XUHIZ } & \text { XUHIZV }_{\text {XUHIZV }} \longrightarrow \text { XUHIZ }\end{array}$ & 6 & $\begin{array}{l}6.592 \\
5.754\end{array}$ \\
\hline
\end{tabular}

a \%1 anlamlılık düzeyini göstermektedir.

Ayrıca çalışmada yer alan dört endekste işlem hacminin endeks değerinin nedeni olduğuna dair herhangi bir bulguya ulaşılamamıştır. XKURY, XUHIZ ve XUMAL endekslerindeki yatırımcıların ise piyasaya ulaşan bilgiler ışı ğında değerlendirmeler yaparak alım-satım kararları verdiği ifade edilebilir. Bu durum yatırımcıların fiyat-hacim ilişkisi açısından rasyonel davranışlar sergilediklerini ortaya koymaktadir.

Tablo 4'te ise fiyat endeksleri (LEnd) ve işlem hacmi (LHac) serileri için yapılan vektör otoregresif analiz (VAR) sonuçları sunulmuştur. Buna göre hacim değişkenini açıklayan tüm modellerin endeks değerini açıklayan tüm modellerden daha yüksek açıklayıcılığa sahip olduğu gözükmektedir. LXKURY, LXUHIZ, LXUMAL ve XUSIN için hacim değişkenini açıklayan modellerin $\mathrm{R}^{2}$ değerleri sırasıyla $0.624,0.785,0.417,0.772$; endeks değerini açıklayan modellerin $\mathrm{R}^{2}$ değerleri ise $0.006,0.004,0.010$ ve 0.017 olarak bulunmuştur. 
Tablo 4. VAR Sonuçları

\begin{tabular}{|c|c|c|c|c|c|c|c|c|}
\hline & \multicolumn{2}{|c|}{ LXKURY } & \multicolumn{2}{c|}{ LXUHIZ } & \multicolumn{2}{c|}{ XUMAL } & \multicolumn{2}{c|}{ LXUSIN } \\
\cline { 2 - 9 } & Fiyat & Hacim & Fiyat & Hacim & Fiyat & Hacim & Fiyat & Hacim \\
\hline C & -0.012 & 1.566 & -0.003 & 0.833 & -0.030 & 3.232 & -0.012 & 0.762 \\
\hline DLEnd(-1) & -0.029 & $0.954^{\mathrm{c}}$ & 0.005 & $1.411^{\mathrm{a}}$ & -0.029 & 0.550 & -0.026 & $2.282^{\mathrm{a}}$ \\
\hline DLEnd(-2) & 0.030 & 0.037 & -0.0003 & 0.384 & 0.015 & -0.137 & 0.046 & $0.966^{\mathrm{c}}$ \\
\hline DLEnd(-3) & 0.042 & -0.066 & 0.016 & 0.531 & $0.056^{\mathrm{b}}$ & -0.177 & $0.066^{\mathrm{b}}$ & 0.174 \\
\hline DLEnd(-4) & -0.031 & -0.140 & -0.019 & -0.310 & -0.034 & $-0.711^{\mathrm{c}}$ & -0.055 & -0.610 \\
\hline DLEnd(-5) & -0.003 & -0.334 & 0.001 & 0.019 & 0.003 & -0.262 & -0.022 & -0.004 \\
\hline DLEnd(-6) & & & & & & & -0.033 & -0.012 \\
\hline LHac(-1) & -0.0003 & $0.530^{\mathrm{a}}$ & $-5.69 \mathrm{E}-$ & $0.560^{\mathrm{a}}$ & -0.001 & $0.533^{\mathrm{a}}$ & $-4.52 \mathrm{E}-$ & $0.510^{\mathrm{a}}$ \\
\hline LHac(-2) & 0.001 & $0.085^{\mathrm{a}}$ & 0.001 & 0.039 & 0.001 & 0.016 & 0.001 & $0.073^{\mathrm{b}}$ \\
\hline LHac(-3) & -0.001 & 0.046 & -0.001 & $0.102^{\mathrm{a}}$ & -0.002 & 0.027 & 0.0002 & $0.114^{\mathrm{a}}$ \\
\hline LHac(-4) & 0.0001 & $0.102^{\mathrm{a}}$ & 0.0002 & $0.104^{\mathrm{a}}$ & 0.002 & $0.114^{\mathrm{a}}$ & 0.0001 & $0.108^{\mathrm{a}}$ \\
\hline LHac(-5) & 0.0006 & $0.152^{\mathrm{a}}$ & -0.001 & $0.147^{\mathrm{a}}$ & 0.001 & $0.144^{\mathrm{a}}$ & 0.001 & $0.148^{\mathrm{a}}$ \\
\hline LHac(-6) & & & & & & & 0.001 & 0.003 \\
\hline R ${ }^{2}$ & 0.006 & 0.624 & 0.004 & 0.785 & 0.010 & 0.417 & 0.017 & 0.772 \\
\hline
\end{tabular}

a, b ve c sirasıyla $\% 1, \% 5$ ve $\% 10$ anlamlılık düzeyini göstermektedir. DLend sirasıyla DLXKURY, DLXUHIZ, DLXUMAL ve DLXUSIN fiyat endekslerini; LHac ise LXKURY, LXUHIZ, LXUMAL ve LXUSIN işlem hacimlerini ifade etmektedir. Optimal gecikme sayıları Akaike ve Schwartz bilgi kriterlerine göre LXKURY, LXUHIZ, LXUMAL için 5; LXUSIN için 6 olarak belirlenmiştir. Bu gecikmelerde değişen varyans ve otokorelasyona rastlanılmamıştır.

XKURY açısından endeks değişkeninin, hem kendi gecikmelerinden hem de işlem hacmi değişkeni gecikmelerinden etkilenmediği belirlenmiştir. İşlem hacmi değişkeni ise endeks değerinin bir önceki değerinden pozitif yönde etkilenmektedir. İlaveten işlem hacminin kendi gecikmeli değerlerinden de pozitif etkilendiği tespit edilmiştir.

XUHIZ ele alındığında ise XKURY'e benzer şekilde endeks değişkeninin, hem kendi gecikmelerinden hem de işlem hacmi değişkeni gecikmelerinden etkilenmediği saptanmıştır. İşlem hacmi değişkeninin ise endeks değerinin bir gün gecikmeli değerinden ve kendi bir, üç, dört ve beş gün gecikmelerinden istatistiksel açıdan anlamlı ve pozitif etkilendiği ortaya konmuştur. Buna göre işlem hacminin ilgili gecikmeli değerleri artar ise hacmin şu anki değeri de artmaktadır.

XUMAL için endeks değerinin kendi üç gün gecikmeli değerinden pozitif yönde etkilendiği belirlenmiştir. İşlem hacminin ise endeks değerinin dört gün gecikmeli değerinden negatif, kendi bir, dört ve beş gün gecikmeli değerlerinden ise pozitif yönde etkilendiği tespit edilmiştir. Buna göre endeks değerinin dört gecikmeli değerindeki artış hacmin şu anki değerini negatif yönde etkilemektedir. 
Bununla birlikte işlem hacminin ilgili gecikmeli değerlerindeki artış ise hacmin şu anki değerine pozitif yönde katkı yapmaktadır.

XUSIN endeks değerinin sadece kendi üç gün gecikmeli değerinden, işlem hacminin ise endeks değerinin bir ve iki gün gecikmeli değerlerinden ve beş gecikmeye kadar kendi değerlerinden pozitif yönde etkilendiği saptanmıştır. Sonuçlar genel olarak değerlendirildiğinde çalışmada yer alan endekslerin değerlerinin işlem hacmindeki artış veya azalışlardan istatistiksel açıdan etkilenmediği söylenebilir. İşlem hacimlerinin ise kendi gecikmeli değerlerinden, nispeten daha çok etkilenmekle birlikte, endeks değerlerindeki değişimlerden de etkilendiği saptanmıştır.

Serilere ait etki-tepki analiz sonuçları ise Tablo 5'te gösterilmiştir. Tablodan görüldüğü üzere XKURY, XUHIZ ve XUMAL için endeks değerlerinin ve işlem hacimlerinin sadece kendi şoklarına istatistiksel açıdan anlamlı tepki verdikleri belirlenmiştir. Buna göre endeks değerlerinin ilk iki dönem boyunca, işlem hacimlerinin ise on dönem boyunca kendi şoklarına pozitif yönde tepki verdiği görülmektedir.

XUSIN için ise diğer üç endeks ile benzer şekilde, endeks fiyatının iki dönem ve işlem hacminin on dönem boyunca kendi tepkilerine istatistiksel açıdan anlamlı pozitif karşılık verdiği tespit edilmiştir. İlaveten ikinci ile dördüncü dönem arasında işlem hacminin endeks fiyatına anlamlı ve pozitif tepki verdiği, ardından ise tepkinin ortadan kaybolduğu belirlenmiştir. Endeks değerinin ise istatistiksel açıdan anlamlı şekilde, altıncı dönem civarında işlem hacmine pozitif, yedinci dönemde ise negatif tepki verdiği ortaya konmuştur.

Tablo 5. Etki-Tepki Analizleri

Response to Cholesky One S.D. (d.f. adjusted) Innovations \pm 2 S.E.

Response of DLXKURY to DLXKURY

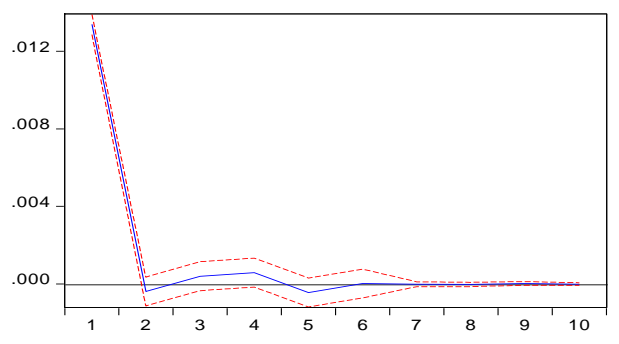

Response of LVKUR to DLXKURY

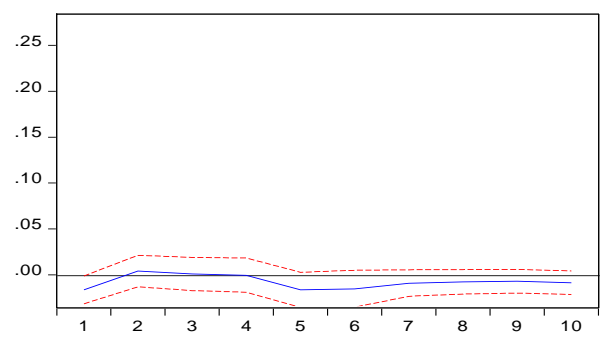

Response of DLXKURY to LVKUR
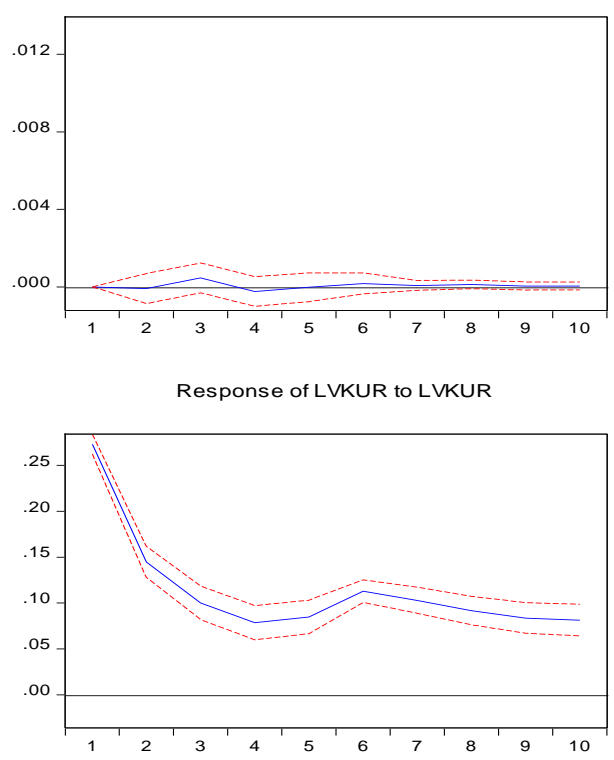
Response to Cholesky One S.D. (d.f. adjusted) Innovations \pm 2 S.E.

Response of DLXUHIZ to DLXUHIZ

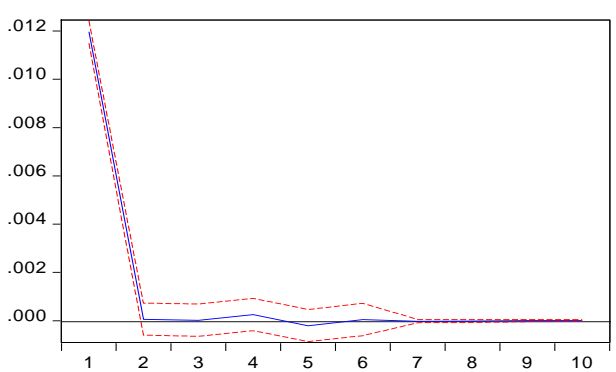

Response of LVHIZ to DLXUHIZ

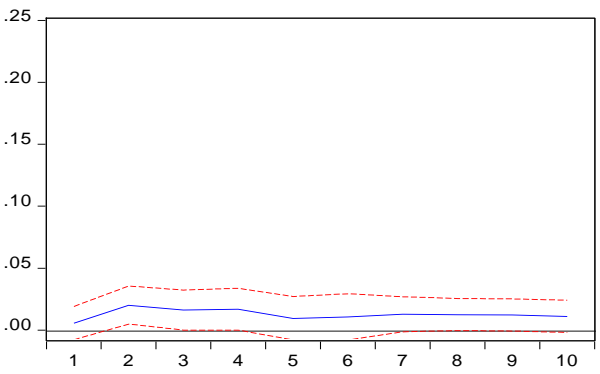

Response to Cholesky One S.

Response of DLXUMAL to DLXUMAL

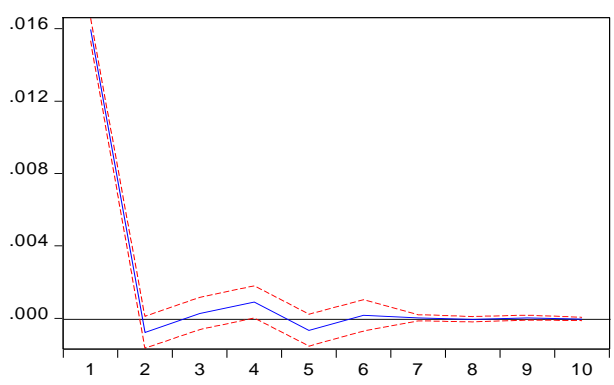

Response of LVMALI to DLXUMAL

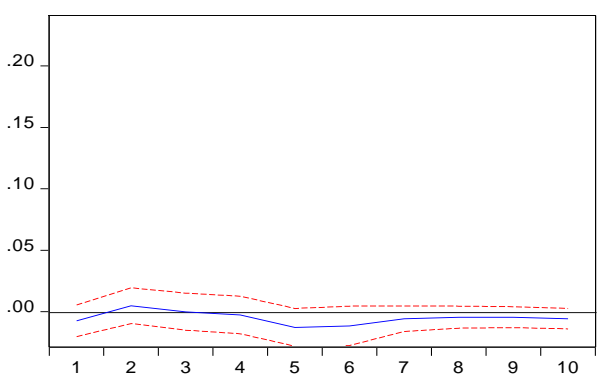

Response of DLXUHIZ to LVHIZ

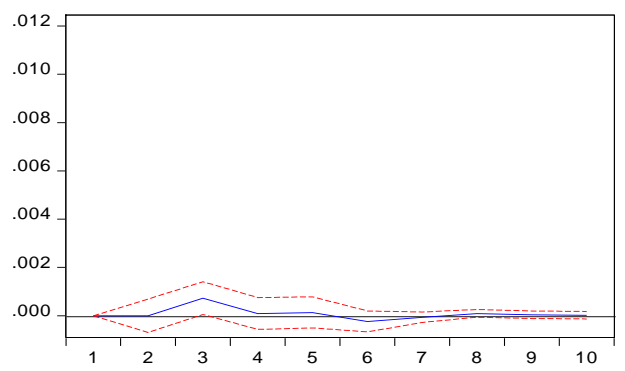

Response of LVHIZ to LVHIZ

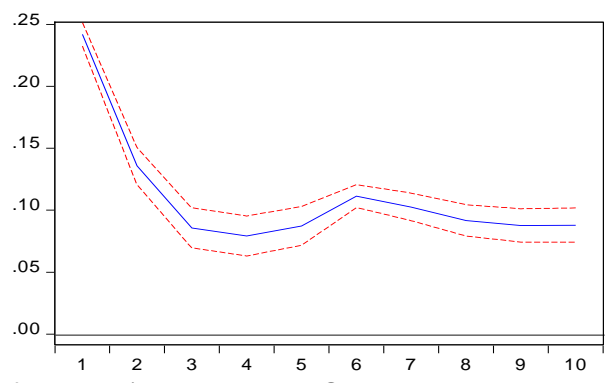

Response of DLXUMAL to LVMALI

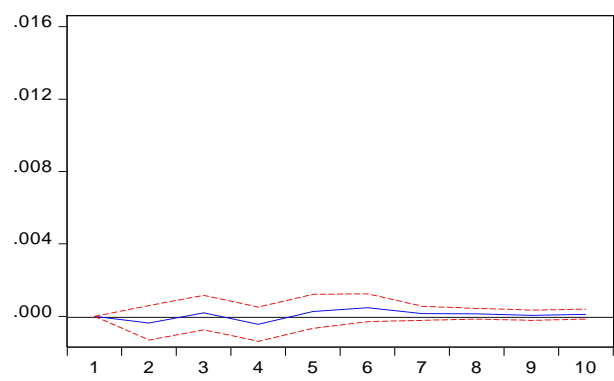

Response of LVMALI to LVMALI

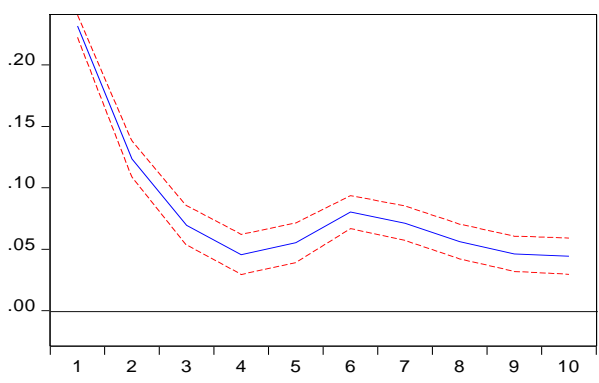


Response to Cholesky One S.D. (d.f. adjusted) Innovations \pm 2 S.E.

Response of DLXUSIN to DLXUSIN

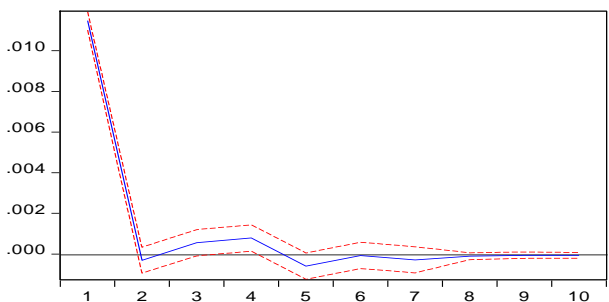

Response of LVSIN to DLXUSIN

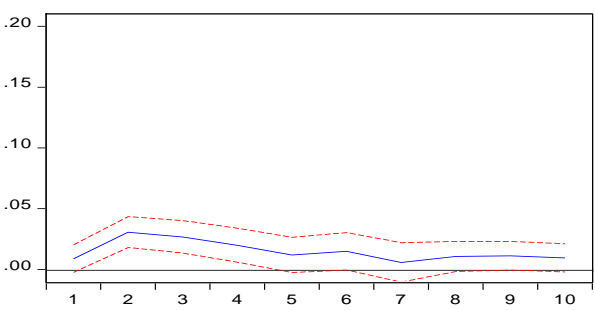

Response of DLXUSIN to LVSIN

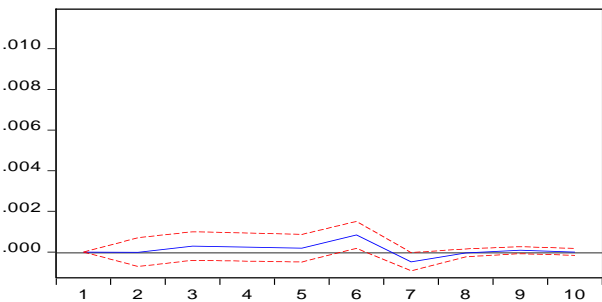

Response of LVSIN to LVSIN

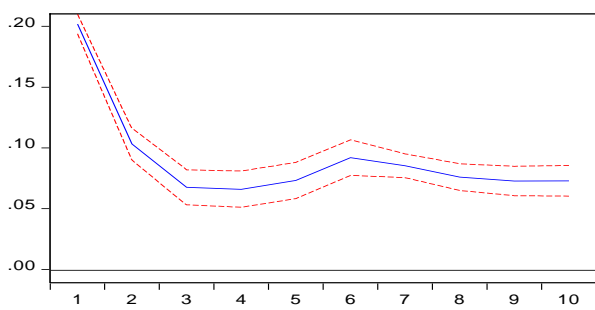

Tablo 6' da ise serilere ilişkin varyans ayrıştırması sonuçları gösterilmiştir. XUSIN, XUMAL, XUHIZ ve XKURY endeks değerlerinin 10 günlük dönemde kendi değerlerinin etkisi altında kaldığı görülmektedir. Diğer bir ifadeyle işlem hacimlerinin 10 günlük dönemde endeks değerleri üzerinde önemsiz seviyede bir etkisi olduğu söylenebilir. Analiz işlem hacimleri açısından değerlendirildiğinde ise benzer sonuçlara ulaşıldığını söylemek mümkündür.

Tablo 6. Varyans Ayrıştırma Sonuçları

\begin{tabular}{|c|c|c|c|c|c|c|}
\hline & \multicolumn{2}{|c|}{ DLXKURY Fiyat Varyans Ayrıstırması } & \multicolumn{2}{c|}{ LXKURY Hacim Varyans Ayrıştırması } \\
\hline Dönem & St. hata & DLEndeks & LHacim & St.hata & DLEndeks & LHacim \\
\hline 1 & 0.013390 & 100.0000 & 0.000000 & 0.273386 & 0.355914 & 99.64409 \\
\hline 2 & 0.013396 & 99.99543 & 0.004572 & 0.309389 & 0.295747 & 99.70425 \\
\hline 3 & 0.013410 & 99.87681 & 0.123190 & 0.325169 & 0.268554 & 99.73145 \\
\hline 4 & 0.013425 & 99.84464 & 0.155363 & 0.334542 & 0.253892 & 99.74611 \\
\hline 5 & 0.013432 & 99.84455 & 0.155453 & 0.345505 & 0.460788 & 99.53921 \\
\hline 6 & 0.013433 & 99.82831 & 0.171693 & 0.363805 & 0.589429 & 99.41057 \\
\hline 7 & 0.013433 & 99.82555 & 0.174448 & 0.378177 & 0.603296 & 99.39670 \\
\hline 8 & 0.013434 & 99.81748 & 0.182523 & 0.389213 & 0.607400 & 99.39260 \\
\hline 9 & 0.013434 & 99.81641 & 0.183590 & 0.398157 & 0.610973 & 99.38903 \\
\hline 10 & 0.013434 & 99.81531 & 0.184688 & 0.406480 & 0.631514 & 99.36849 \\
\hline & DLXUHIZ Fiyat Varyans Ayrıştırması & LXUHIZ Hacim Varyans Ayriştırması \\
\hline Dönem & St. hata & DLEndeks & LHacim & St.hata & DLEndeks & LHacim \\
\hline 1 & 0.011968 & 100.0000 & 0.000000 & 0.242106 & 0.053839 & 99.94616 \\
\hline 2 & 0.011969 & 100.0000 & $1.32 \mathrm{E}-06$ & 0.278292 & 0.559534 & 99.44047 \\
\hline 3 & 0.011991 & 99.63280 & 0.367196 & 0.291631 & 0.816486 & 99.18351 \\
\hline 4 & 0.011994 & 99.62796 & 0.372039 & 0.302667 & 1.067255 & 98.93275 \\
\hline 5 & 0.011996 & 99.61565 & 0.384354 & 0.315147 & 1.073163 & 98.92684 \\
\hline 6 & 0.011999 & 99.57485 & 0.425149 & 0.334424 & 1.052239 & 98.94776 \\
\hline 7 & 0.011999 & 99.57162 & 0.428382 & 0.350031 & 1.093486 & 98.90651 \\
\hline 8 & 0.011999 & 99.56573 & 0.434272 & 0.362045 & 1.140954 & 98.85905 \\
\hline
\end{tabular}


Sinem Eyüboğlu \& Kemal Eyüboğlu / Borsa İstanbul Sektör Endekslerinde Fiyat ile İşlem Hacmi İlişkisi

\begin{tabular}{|c|c|c|c|c|c|c|}
\hline 9 & 0.011999 & 99.56470 & 0.435303 & 0.372687 & 1.182417 & 98.81758 \\
\hline 10 & 0.011999 & 99.56442 & 0.435576 & 0.383069 & 1.202410 & 98.79759 \\
\hline & \multicolumn{3}{|c|}{ DLXUMAL Fiyat Varyans Ayrıştırması } & \multicolumn{3}{|c|}{ LXUMAL Hacim Varyans Ayrıştırması } \\
\hline Dönem & St. hata & DLEndeks & LHacim & St.hata & DLEndeks & LHacim \\
\hline 1 & 0.015960 & 100.0000 & 0.000000 & 0.231771 & 0.106205 & 99.89379 \\
\hline 2 & 0.015983 & 99.94824 & 0.051764 & 0.262685 & 0.115548 & 99.88445 \\
\hline 3 & 0.015986 & 99.93305 & 0.066947 & 0.271698 & 0.108065 & 99.89193 \\
\hline 4 & 0.016018 & 99.85619 & 0.143814 & 0.275515 & 0.115633 & 99.88437 \\
\hline 5 & 0.016034 & 99.82778 & 0.172221 & 0.281300 & 0.324647 & 99.67535 \\
\hline 6 & 0.016042 & 99.74212 & 0.257884 & 0.292754 & 0.459793 & 99.54021 \\
\hline 7 & 0.016042 & 99.73281 & 0.267188 & 0.301305 & 0.471532 & 99.52847 \\
\hline 8 & 0.016043 & 99.72585 & 0.274151 & 0.306539 & 0.478195 & 99.52181 \\
\hline 9 & 0.016043 & 99.72489 & 0.275107 & 0.310033 & 0.489558 & 99.51044 \\
\hline \multirow[t]{2}{*}{10} & 0.016044 & 99.71989 & 0.280114 & 0.313234 & 0.514375 & 99.48562 \\
\hline & \multicolumn{3}{|c|}{ DLXUSIN Fiyat Varyans Ayrıştırması } & \multicolumn{3}{|c|}{ LXUSIN Hacim Varyans Ayrıştırması } \\
\hline Dönem & St. hata & DLEndeks & LHacim & St.hata & DLEndeks & LHacim \\
\hline 1 & 0.011479 & 100.0000 & 0.000000 & 0.202203 & 3.191377 & 96.80862 \\
\hline 2 & 0.011483 & 99.99994 & $6.32 \mathrm{E}-05$ & 0.229082 & 3.946812 & 96.05319 \\
\hline 3 & 0.011500 & 99.93521 & 0.064789 & 0.240334 & 5.005790 & 94.99421 \\
\hline 4 & 0.011530 & 99.89100 & 0.109001 & 0.250005 & 7.411530 & 92.58847 \\
\hline 5 & 0.011547 & 99.86457 & 0.135426 & 0.260777 & 10.343117 & 89.65688 \\
\hline 6 & 0.011578 & 99.33265 & 0.667353 & 0.276906 & 13.253341 & 86.74666 \\
\hline 7 & 0.011592 & 99.16144 & 0.838556 & 0.289793 & 13.008878 & 86.99112 \\
\hline 8 & 0.011592 & 99.16030 & 0.839701 & 0.299753 & 12.937464 & 87.06254 \\
\hline 9 & 0.011593 & 99.15447 & 0.845530 & 0.308653 & 12.901002 & 87.09900 \\
\hline 10 & 0.011593 & 99.15449 & 0.845505 & 0.317292 & 12.835450 & 87.16455 \\
\hline
\end{tabular}

Sadece XUSIN için endeks değerinin açıklayıcılığı birinci dönemde \%3 civarında iken, beşinci dönemden itibaren \%10'un üzerine çıkmakta, onuncu dönemde ise açılayıcılık \%13 civarında olmaktadır. Elde edilen bu bulgu, XUSIN için endeks değerinin işlem hacminin nedeni olduğunu ortaya koyan Toda-Yamamoto nedensellik testi sonuçlarını destekler niteliktedir.

\section{SONUÇ}

Literatürde yer alan çalışmalar hisse fiyatları ve işlem hacimleri arasındaki ilişkilerin piyasanın genel yapısı hakkında düzenleyicilere, spekülatörlere, finansal varlık fiyatlandırması ile ilgilenen piyasa katılımcılarına ipuçları verebileceğini ortaya koymuştur. Çalışmada, 01.01.2012-02.01.2018 dönemi için günlük veriler kullanılarak Borsa İstanbul Sınai, Hizmet, Mali ve Kurumsal Yönetim endekslerinde işlem hacmi ve fiyat arasındaki ilişki araştııılmıştır. Endeks değerleri ile endeks işlem hacimleri aynı seviyede durağan olmadığından seriler arasındaki nedensellik ilişkisi Toda-Yamamoto nedensellik testi ile araştırılmıştır. Sonuçlar Borsa İstanbul Sınai endeksinde, endeks değerinden, endeks işlem hacmine doğru tek yönlü nedensellik ilişkisi olduğunu ortaya koymuştur. Bu sonuç, Chen vd. (2001), Gökçe (2002), Badhani \& Suyal (2005), Gündüz \& Hatemi-J (2005), Sarığlu (2007), Umutlu (2008), Gaygusuz (2008), Elmas \& Temurlenk (2009), Elmas \& Yıldırım (2010), Çukur vd. (2012), Taş vd. (2016) ve Büberkökü (2017)'nün çalışma sonuçları ile örtüşmektedir. Mali, hizmetler ve kurumsal yönetim endekslerinde ise endeks değerleri ile 
endeks hacimleri arasında bir nedensellik ilişkisine rastlanılmamıştır. Sonuçlar Granger \& Morgenstern (1963) Darrat vd. (2003) ve Bayrakdaroğlu \& Nazlığlu (2009)'nun sonuçları ile örtüşmektedir.

VAR analizi endeks değerlerinin ve işlem hacimlerinin gecikmeli değerlerinin, özellikle işlem hacimlerini etkilediğini göstermiştir. Etki-tepki analizleri ise XKURY, XUHIZ, XUMAL ve XUSIN endeksleri için endeks fiyatının iki dönem ve işlem hacminin on dönem boyunca kendi tepkilerine anlamlı ve pozitif tepki verdiğini göstermiştir. Ayrıca işlem hacminin endeks fiyatına ikinci ile dördüncü dönem arasında pozitif; endeks değerinin ise altıncı dönem civarında işlem hacmine pozitif, yedinci dönemde ise negatif ve anlamlı tepki verdiği belirlenmiştir. Varyans ayrıştırma sonuçları ise benzer şekilde XUSIN, XUMAL, XUHIZ ve XKURY endeks değerlerinin on günlük dönemde kendi değerlerinin etkisi altında kaldığını ortaya koymuştur. İşlem hacimleri açısından ise sadece XUSIN endeksinde, hacim üzerinde endeks değerinin önemli düzeyde bir açıklayıcıllı̆ı olduğu saptanmıştır. Bu sonuç, XUSIN için endeks değerinin işlem hacminin nedeni olduğunu ortaya koyan Toda-Yamamoto nedensellik testi sonuçlarını destekler niteliktedir.

Sonuçlar Borsa İstanbul Sınai endeksinde, endeks değerinden, endeks işlem hacmine doğru tek yönlü nedensellik ilişkisi olduğunu ortaya koymuştur. Bu sonuç, Chen vd. (2001), Gökçe (2002), Badhani \& Suyal (2005), Gündüz \& Hatemi-J (2005), Sarığlu (2007), Umutlu (2008), Gaygusuz (2008), Elmas \& Temurlenk (2009), Elmas \& Yıldırım (2010), Çukur vd. (2012), Taş vd. (2016) ve Büberkökü (2017)'nün çalışma sonuçları ile örtüşmektedir. Bu durum sinai endeksinin zayıf kuvvetli formda bile etkin olmadığını göstermektedir.

Mali, hizmetler ve kurumsal yönetim endekslerinde ise endeks değerleri ile endeks hacimleri arasında bir nedensellik ilişkisine rastlanılmamıştır. Sonuçlar Granger \& Morgenstern (1963) Darrat vd. (2003) ve Bayrakdaroğlu \& Nazlığlu (2009)'nun sonuçları ile örtüşmektedir. Bu durum mali, hizmetler ve kurumsal yönetim endekslerinin zayıf kuvvetli formda etkin olduğunu ortaya koymaktadır. Çünkü bu piyasalarda geçmiş piyasa verilerini kullanarak ilave bir kazanç sağlanamamakta, hisse senedi fiyatlarının rassal olarak hareket ettiği söylenebilir.

Sonuçlar genel olarak değerlendirildiğinde, Gürültücüler Hipotezi'nin Sınai endeksinde geçerli olduğu görülmektedir. Buna göre; Sinai endeksindeki yatırımcıların öncelikle fiyat hareketlerini takip ettikleri ve fiyat hareketlerine bağlı olarak alım-satım kararlarını verdikleri söylenebilir. Bu nedenle, XUSIN hisse senetlerinde kısa vadede geçici bir yanlış fiyatlama olabilecektir. XKURY, XUHIZ ve XUMAL için işlem hacminin fiyatların nedeni olmaması XKURY, XUHIZ ve XUMAL endekslerinin etkinliğini göstermektedir. Buna göre işlem hacminden hareketle XKURY, XUHIZ ve XUMAL sektör endeksinin nasıl hareket edeceğinin tahmin edilemeyeceği, diğer bir ifade ile hacim açısından teknik analiz yöntemlerine dayalı alım-satım kararlarının bu endekslerde etkin olmayacağı ifade edilebilir. Çünkü teknik analizde işlem hacmi, gelecekteki fiyat hareketlerinin belirlenmesinde kullanılan önemli değişken olarak karşımıza 
çıkmaktadır. Bu endekslerde yatırımcıların piyasaya ulaşan yeni bilgiler ışı̆̆ında değerlendirmeler yaparak hisse fiyatlarını etkilediği söylenebilir.

\section{KAYNAKÇA}

Abdioğlu, Z. (2013). Ücret-Fiyat Spirali: Türk İmalat Sanayi Örneği. Yönetim ve Ekonomi Araştırmaları Dergisi, Cilt 11, Say1 19, 45-58.

Akar, C, (2008). Hisse Senedi Fiyatlarıyla Yabancı İşlem Hacmi Arasındaki Nedensellik: TodaYamamato Yaklaşımı. Muhasebe ve Finans Dergisi, Cilt 37, 185-191.

Al-Deehani, T. M. (2007). Modeling Asymmetry in The Price-Volume Relation: Evidence From Nine Stock Markets. Investment Management and Financial Innovations, Vol 4, Issue 4, $8-15$.

Badhani, K. N. and Suyal, J. (2005). Stock Price-Volume Causality at Index Level. http://papers.ssrn.com/sol3/papers.cfm?abstract_id=874914, (02.12.2017).

Bayrakdaroğlu, A., Nazlığlu, Ş. (2009). Hisse Senedi Fiyat-Hacim İlişkisi: İMKB'de İşlem Gören Bankalar İçin Doğrusal ve Doğrusal Olmayan Granger Nedensellik Analizi. İktisat, İsletme ve Finans Dergisi, Cilt 24, 85-109.

Boyacıoğlu, M. A., Güvenek, B. ve Alptekin, V. (2010). Getiri Volatilitisi İle İşlem Hacmi Arasındaki İlişki: İMKB'de Ampirik Bir Çalışma. Journal of Accounting \& Finance, Cilt 48, 200-215.

Büberkökü, Ö. (2017). İşlem Hacmi İle Hisse Senedi Getirileri Arasındaki İlişkinin İncelenmesi: Banka Hisselerine Dayalı Bir Analiz. Mehmet Akif Ersoy Üniversitesi Sosyal Bilimler Enstitüsü Dergisi, Cilt 9, Say1 19, 457-482.

Chen, G-M., Firth, M. and Rui, O. M. (2001). The Dynamic Relation between Stock Returns, Trading Volume and Volatility. Financial Review, Vol 36, Issue (3), 153-174.

Chuang, W., Liu, H. H. and Susmel, R. (2012). The Bivariate GARCH Approach to Investigating the Relation between Stock Returns, Trading Volume, and Return Volatility. Global Finance Journal, Vol 23, Issue (1), 1-15.

Clark, P. K. (1973). A Subordinated Stochastic Process Model With Finite Variance for Speculative Prices. Econometrica, Vol 41, 135-155.

Copeland, T. E. (1976). A Model of Asset Trading under the Assumption of Sequential Information Arrival. The Journal of Finance, 31(4), 1149-1168.

Copeland, L. (1991). Cointegration Tests with Daily Data. Oxford Bulletin of Economics and Statistics, Vol 53, Issue 2, 185-198.

Çukur, S., Gümrah, Ü. ve Gümrah, M.Ü. (2012). İstanbul Menkul Kıymetler Borsasında Hisse Senedi Getirileri ve İşlem Hacmi İlişkisi. Niğde Üniversitesi İIBF Dergisi, Cilt 5, Sayı 1, 20-35.

Darrat, A. F., Rahman, S. and Zhong, M. (2003). Intraday Trading Volume and Return Volatility of the DJIA Stocks: A Note. Journal of Banking \& Finance, Vol 27, Issue 10, 2035-2043.

Darwish, M. (2012). Testing the Contemporaneous and Causal Relationship between Trading Volume and Return in the Palestine Exchange. International Journal of Economics and Finance, Vol 4, Issue 4, 182-192.

De Long, J. B., Shleifer, A., Summers, L. H. and Waldmann, R. J. (1990). Noise Trader Risk in Financial Markets. Journal of Political Economy, Vol 98, Issue 4, 703-738.

Deo, M., Srinivasan, K., Devanadhen, K. (2008). The Empirical Relationship between Stock Returns, Trading Volume and Volatility: Evidence from Select Asia-Pacific Stock Market. European Journal of Economics, Finance and Administrative Sciences, Vol 12, 58-68.

Dickey, D.A. and Fuller, W.A. (1981). Likelihood Ratio Statistics for Autoregressive Time Series with a Unit Root. Econometrica, Vol 49, Cilt 4, 1057-1072.

Elmas, B. ve Yıldırım, M. (2010). Kriz Dönemlerinde Hisse Senedi Fiyatı İle İşlem Hacmi İlişkisi: IMMKB’DE İşlem Gören Bankacılık Sektör Hisseleri Üzerine Bir Uygulama. Atatürk Üniversitesi İktisadi ve İdari Bilimler Dergisi, Cilt 24, Say1 2, 37-46.

Elmas, B., Temurlenk, S. (2009). Hisse Senedi Fiyatı-İşlem Hacmi Arasındaki Granger Nedensellik : İMKB'de Hisse Bazlı Bir Analiz. IMKB Dergisi, Cilt 11, Sayı 43, 1-12. 
Epps, T. and Epps M. (1976). The Stochastic Dependence of Security Price Changes and Transaction Volumes: Implications for the Mixture-of-Distributions Hypothesis. Econometrica, Vol 44, 305-321.

Eun, C. S. and Shim, S. (1989). International Transmission of Stock Market Movements. The Journal of Financial and Quantitative Analysis, Vol 24, Issue 2, 241-256.

Fama, E. (1970). Efficient Capital Markets: A Review of Theory and Emprical Work. Journal of Finance, Vol 25, Issue 2, 383-417.

Gallant, R., Rossi, P. and Tauchen, G. (1992). Stock Prices and Volume, Review of Financial Studies, Vol 5, 199-242.

Gaygusuz, F. (2008). Hisse Senedi Piyasalarında İşlem Hacmi-Volatilite İlişkisi ve İMKB'ye Ait Bir Uygulama. Çukurova Üniversitesi İIBF Dergisi, Cilt 12, Sayı 1, 34-35.

Gökçe, A. (2002). İMKB'de Fiyat-Hacim İlişkisi: Granger Nedensellik Testi. Gazi Üniversitesi Iktisadi ve İdari Bilimler Fakültesi Dergisi, Cilt 4, Sayı 3, 43-48.

Granger, C. W. and Morgenstern, O. (1963). Spectral Analysis of New York Stock Market Prices. Kyklos, 16(1), 1-27.

Gündüz, L. and Hatemi-J, A. (2005). Stock Price and Volume Relation in Emerging Markets. Emerging Markets Finance and Trade, Vol 41, Issue 1, 29-44.

Hiemstra, C. and Jones, J. D. (1994). Testing for linear and nonlinear Granger causality in the Stock Price-Volume Relation. The Journal of Finance, Vol 49, Issue 5, 1639-1664.

Jennings, R. H., Starks, L. T. and Fellingham, J. C. (1981). An Equilibrium Model of Asset Trading with Sequential Information Arrival. Journal of Finance, Vol 36, Issue 1, 143-161.

Jiranyakul, K. (2016). Dynamic Relationship between Stock Return, Trading Volume, and Volatility in the Stock Exchange of Thailand: Does the US Subprime Crisis Matter? MPRA Paper, University Library of Munich, Germany.

Karpoff, J.M. (1987). The Relation between Price Changes and Trading Volume: A Survey. Journal of Financial and Quantitative Analysis, Vol 22, Issue 1, 109-126.

Lamoureux, C. G. and Lastrapes, W. D. (1990). Heteroskedasticity in Stock Return Data: Volume Versus GARCH Effects. Journal of Finance, Vol 45, Issue 1, 221-229.

Moosa, I. A. and Silvapulle, P. (2000). The Price-Volume Relationship in the Crude Oil Futures Market Some Results Based On Linear And Nonlinear Causality Testing. International Review of Economics \& Finance, Vol 9, Issue 1, 11-30.

Nalın, H. T. and Güler, S. (2013). İstanbul Menkul Kıymetler Borsası'nda İşlem Hacmi İle Getiri İlişkisi. Muhasebe ve Finansman Dergisi, 135-148.

Ong, M. A. (2015). An Information Theoretic Analysis of Stock Returns, Volatility and Trading Volumes. Applied Economics, Vol 47, Issue 36, 1-15.

Pathirawasam, C. (2011). The Relationship between Trading Volume and stock Returns. Journal of Competitiveness, Vol 3, 41-49.

Phillips, P. C. and Perron, P. (1988). Testing for a Unit Root in Time Series Regression. Biometrika, Vol 75, Issue 2, 335-346.

Saatcioglu, K. and Starks, L. T. (1998). The Stock Price-Volume Relationship in Emerging Stock Markets: The Case of Latin America. International Journal of Forecasting, Vol 14, Issue 2, 215-225.

Sarıŏlu, E. S. (2007). Hisse Senedi Fiyatları İle İşlem Hacmi Arasındaki İlişki: İMKB Üzerine Bir Çalışma. 11. Ulusal Finans Sempozyumu, 10-13 Ekim, 325-336.

Sims, C. A. (1980). Macroeconomics and Reality. Econometrica, Vol 48, Issue 1, 1 - 48.

Taş, O., Tokmakçıoğlu, K. ve Çevikcan, G. (2016). Borsa İstanbul'da Pay Senedi Getirileri İle İşlem Hacmi Arasındaki İlişki. Dokuz Eylül Üniversitesi Sosyal Bilimler Enstitüsü Dergisi, Vol 18, Issue 1, 11-30.

Tauchen, G. and Pitts, M. (1983). The Price Variability-Volume Relationship on Speculative Markets. Econometrica, Vol 51, 485-505.

Toda, H. Y. and Yamamoto, T. (1995). Statistical Inference in Vector Autoregressions with Possibly Integrated Process. Journal of Econometrics, Vol 66, 225-250.

Ulusoy, A., Yamak, R. ve Şahingöz, B. (2016). Faiz Dışı Dengenin Ekonomik Büyüme ve İşsizlik Üzerine Etkisi. Ekonomi Bilimleri Dergisi, Cilt 8, Sayı 1, 1-33. 
Umutlu, G. (2008). İşlem Hacmi ve Fiyat Değişimleri Arasındaki Nedensellik ve Dinamik İlişkiler: İMKB'de Bir Ampirik İnceleme. Gazi Üniversitesi İktisadi ve İdari Bilimler Fakültesi Dergisi, Cilt 10, Say1 1, 1-16.

Yılanc1, V., Bozoklu, Ş. (2014). Türk Sermaye Piyasasında Fiyat ve İşlem Hacmi İlişkisi: Zamanla Değişen Asimetrik Nedensellik Analizi. Ege Akademik Bakış, Cilt 14, 211-220.

Yörük, N., Erdem, C., Erdem ve M. S. (2006), Testing for Linear and Nonlinear Granger Causality in the Stock Price-Volume Relation: Turkish Banking Firms' Evidence. Applied Financial Economics Letters, Vol 2, Issue 2, 165-171.

Zor, İ., Bozkurt, İ. ve Öksüz, Ö. G. S. (2016). Asimetrik Bilgi Düzeyinin Fiyat-Hacim İlişkisi Üzerindeki Etkisi: Borsa İstanbul Örneği. Anadolu Üniversitesi Sosyal Bilimler Dergisi, Cilt 16, Say1 1,119-135.

\section{SUMMARY}

Today, stock price-volume graphs are used frequently by technical analysts while making investment decisions. Price and volume are two important elements of any economic balance and they are determined by common market dynamics. Therefore, it is generally believed that these two variables have a very close relationship. In the study, the relationship between transaction volume and price is examined in Borsa Istanbul Industrial, Service, Financial and Corporate Governance indices by using daily data for $01.01 .2012-02.01 .2018$ period. The causality test results showed that there is a one-way causality relationship from index value to index volume in Borsa İstanbul Industrial Index.

Thus, it is seen that the Noise-Traders Hypothesis is valid in industrial index. Therefore; it can be concluded that the investors in the industrial index follow the price movements firstly and make their trading decisions based on the price movements. For this reason, XUSIN stocks may be a temporary mispricing in the short term. The fact that the transaction volume for XKURY, XUHIZ and XUMAL is not the cause of the prices shows the effectiveness of XKURY, XUHIZ and XUMAL indices. Accordingly, it can be stated that XKURY, XUHIZ and XUMAL sector indices cannot be predicted in terms of transaction volume. In other words, it can be stated that trading decisions based on technical analysis methods in terms of volume will not be effective in these indices. In these indices, it can be concluded that investors have evaluated the stock prices in the light of new information reaching the market. 